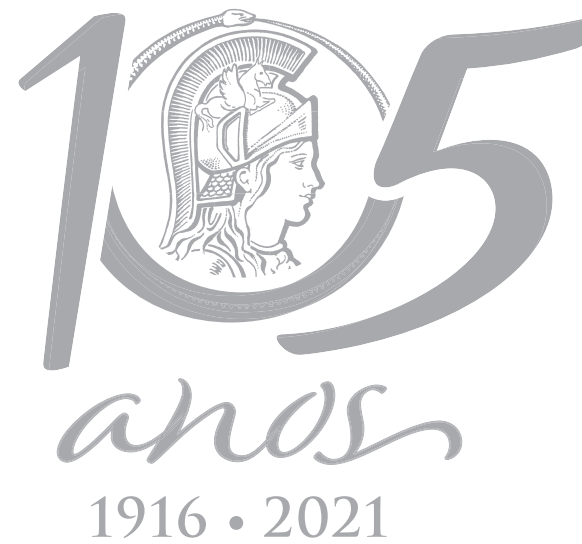

$1916 \cdot 2021$

\title{
Light quality and sealing type affect in vitro growth and development of Capsicum frutescens cultivars
}

\author{
TAINARA GRIS, MARCOS V.M. PINHEIRO, LEONARDO A. THIESEN, ANDERSON R. \\ WEBLER, DIÉSSICA L. JUNGES, EVANDRO HOLZ, IURI NAIBO, DIEGO S. BATISTA, \\ WAGNER C. OTONI \& DENISE SCHMIDT
}

\begin{abstract}
The aim of this work was to evaluate the effect of five light qualities [fluorescent lamps ( $\mathrm{FL})$; white $(\mathrm{WL})$, red $(\mathrm{RL})$, blue $(\mathrm{BL})$, or red/blue LEDs $(\mathrm{RBL})$ ] and two types of flask sealing (with or without porous membranes) in the in vitro germination and growth of two Capsicum frutescens cultivars (Espaguetinho and Cayenne). For this, two seeds were inoculated per flask $\left(350 \mathrm{~mL}\right.$ ) containing $50 \mathrm{~mL}$ of MS medium with $100 \mathrm{mg} \mathrm{L}^{-1}$ myo-inositol, $30 \mathrm{~g} \mathrm{~L}^{-1}$ sucrose, $6.0 \mathrm{~g} \mathrm{~L}^{-1}$ agar, and $\mathrm{pH} 5.8 \pm 0.1$. The plants were kept under culture room conditions ( 16 - $\mathrm{h}$ photoperiod, $25 \pm 2{ }^{\circ} \mathrm{C}$ and irradiance of $40 \mu \mathrm{mol} \mathrm{m} \mathrm{s}^{-2}$ ). The experiment was arranged in CRD, $2 \times 5 \times 2$ factorial scheme (Cultivar $X$ Light qualities $X$ Sealing type). At 42 days, the following traits were evaluated: percentage of germination; root and shoot length; number of green leaves, senescent leaves and nodal segments; and fresh and dry weight. Plants grown under RL and BRL, showed greater number of green leaves, and longer shoots and roots. The use of porous membranes remarkably reduced the number of senescent leaves. Thus, the use of porous membranes, RL and $B R L$ are recommended since they improve growth and development of pepper in vitro.
\end{abstract}

Key words: Pepper, Light-emitting diodes (LEDs), porous membranes, gas exchange.

\section{INTRODUCTION}

Pepper (Capsicum sp.) is a horticultural crop cultivated in tropical and temperate regions. Besides its high ornamental and medicinal value, its fruits are used in jellies, in the manufacture of preserved foods, sauces, spices or powdered for seasoning (Sanatombi \& Sharma 2007, Valnir Júnior et al. 2015, Swamy et al. 2017). Among the uses of these plants, the medicinal application due to the high contents of capsaicin alkaloid in the fruits, which confers the pepper pungency of dihydrocapsaicin, homodihidrocapsaicin and homocapsaicin, all known as capsaicinoids (Davis et al. 2007, Mueller-Seitz et al. 2008). The capsaicinoids are synthesized in the fruits placenta and some factors such as temperature, nutrient availability, nitrate fertilization and carbon availability may affect the accumulation of these substances (Garruña-Hernandez et al. 2013, Aguilar 2016).

Usually, the propagation of Capsicum plants is performed sexually. However, this seed-based propagation method can be limited by several pathogens, such as fungi, nematodes and viruses. So, in vitro propagation stands out as an alternative to allow a rapid production and multiplication of this genus, generating uniform, large-scale and disease-free plant material (Sanatombi \& Sharma 2007, Chandra et al. 2010). Considering the susceptibility of peppers to diseases and pests, the improvement of tissue 
culture techniques is very important. However, some authors report recalcitrance of the genus Capsicum for in vitro regeneration, which may hinder the applicability of genetic improvement techniques and molecular biology (Kothari et al. 2010, Mohamed \& Alsadon 2011, Batista et al. 2017, Gammoudi et al. 2018). In addition, some authors report that this recalcitrance has a positive correlation to ethylene levels produced during in vitro growth and development, making it a limiting factor for species such as pepper (Santana-Buzzy et al. 2006, Batista et al. 2013, Gammoudi et al. 2018). Also, among the factors required for the success of in vitro regeneration, are the genotype, the light regime and the effect of gas exchange (Dabauza \& Peña 2001, OchoaAlejo \& Ramirez-Malagon 2001, Mohamed \& Alsadon 2011, Batista et al. 2017). Especially in peppers of the genus Capsicum, the physiological responses are extremely genotype-dependent, which makes necessary studies directed to the cultivars of interest (Dabauza \& Peña 2001, Steinitz et al. 2003).

In customary in vitro plant cultivation tight sealed flasks have been widely used. Remarkably, there is a restricted gas exchange leading to accumulation of ethylene and other gases, reduced gas exchange, low $\mathrm{CO}_{2}$ concentration, high carbohydrate, low photosynthetic and transpiratory rates of the plants, lessening their rate of multiplication and survival during acclimatization (Aragón et al. 2010, Kozai 2010, Xiao et al. 2011, Nguyen et al. 2016, Batista et al. 2018). Notably, to overcome such constraints and improve the in vitro environment, porous membranes have been used. They promote gas exchanges resulting in increased inner $\mathrm{CO}_{2}$ concentrations, reduced humidity and ethylene concentrations, stimulating photosynthesis and benefiting explants growth and allowing the photoautotrophic propagation (Kozai \& Kubota 2001, Saldanha et al. 2012). Ultimately, it favors to rustify in vitro grown plants during acclimatization, which is a delicate step for tissue culture.

The development and biological processes of the plants are influenced by light spectrum stimuli, interfering in the size and number of organs, number of shoots, seed germination, determination of growth and flowering habits, fruiting, among others (Morelli \& Ruberti 2000, Carvalho et al. 2011). Under in vitro conditions, light stands out as an important factor, supporting plant growth and development (Muleo et al. 2001, Pawtowska et al. 2018). Although these plants depend on the sugars present in the culture medium as energy source, light is still an important regulator of plants development (Pawłowska et al. 2018). Advances in light technology led the researchers to explore light-emitting diodes (LEDS) in tissue culture, demonstrating great potential for their use in in vitro cultivation due to long lifespan, low power consumption, small mass and volume, low radiant heat emission, high wavelength specificity and capacity of emitting specific spectral qualities (Hung et al. 2016, Batista et al. 2018, Pawtowska et al. 2018).

The wavelengths of red and blue light are the focus of current research due to their regulatory effects on plant development, since they promote photosynthesis (Bantis et al. 2016). The red light $(660 \mathrm{~nm})$ is efficiently absorbed by photosynthetic pigments (chlorophyll and carotenoids) and stimulates the phytochrome fotoreceptor. The blue light (400-500 nm), by its turn, performs a variety of important photomorphogenic roles in plants, including stomatal opening, stem elongation and phototropism (Pawłowska et al. 2018).

Therefore, this study hypothesis that different light qualities and sealing types modify the in vitro germination and growth of Capsicum frutescens cultivars. 


\section{MATERIALS AND METHODS}

\section{Plant material and growing conditions}

The experiment was carried out at the Tissue Culture and Aromatic Extracts Laboratory of the Federal University of Santa Maria, Frederico Westphalen, RS, Brazil.

Seeds from two cultivars of Capsicum frutescens namely 'Espaguetinho' and 'Cayenne' (ISLA $\left.{ }^{\circledast}\right)$ were disinfested in $70 \%$ alcohol for 1 $\mathrm{min}$, followed by sodium hypochlorite $(\mathrm{NaClO})$ at $0.8 \%$ active chlorine for $15 \mathrm{~min}$, and four rinses in autoclaved distilled water. After disinfestation, two seeds were inoculated into each glass flask (350 mL capacity) containing $50 \mathrm{~mL}$ of macronutrients, micronutrients and vitamins of the MS culture medium (Murashige \& Skoog 1962), with $100 \mathrm{mg} \mathrm{L}^{-1}$ myo-inositol, $30 \mathrm{~g}$ $\mathrm{L}^{-1}$ sucrose, and $6.0 \mathrm{~g} \mathrm{~L}^{-1}$ granulated agar. The $\mathrm{pH}$ was adjusted to $5.8 \pm 0.1$, prior to autoclaving at $120^{\circ} \mathrm{C}, 108 \mathrm{kPa}$, for $15 \mathrm{~min}$. The cultures were kept under culture room conditions with a 16-h photoperiod, temperature of $25 \pm 2{ }^{\circ} \mathrm{C}$ and irradiance of $72 \mu \mathrm{mol} \mathrm{m} \mathrm{m}^{-2} \mathrm{~s}^{-1}$ from five different light qualities: four fluorescent lamps (FL, Luz do Dia Especial, 40 W, Osram, Brazil); two white LEDs (WL), red LEDs (RL), blue LEDs (BL) or red/ blue LEDs (RBL, 60 and 40\%, respectively), TEC LAMP $^{\circ}$. In addition, two types of sealing were used: rigid metal lids without orifice and rigid metal lids with two $10 \mathrm{~mm}$-diameter holes covered by porous membranes, which were prepared following the methodology proposed by Saldanha et al. (2012).

\section{Analyzed characters}

After 42 days of in vitro cultivation the following characters were evaluated: percentage of germination, root and shoot length, number of green leaves, number of nodes, fresh and dry weight, number of senescent leaves and photosynthetic pigments (chlorophyll $a, b$ and carotenoids).

\section{Quantification of photosynthetic pigments}

Three $3 \mathrm{~mm}$-diameter leaf discs were removed from the second and third leaf of the apex towards the base and incubated in $3 \mathrm{~mL}$ of saturated dimethylsulfoxide (DMSO) with $\mathrm{CaCO}_{3}$, following the modified methodology proposed by Santos et al. (2008). The discs remained in glass tubes covered with aluminum and kept in the dark for 48 hours at room temperature. After this, the absorbance of the samples was determined using a $10 \mathrm{~mm}$ quartz cuvette of optical path in Bel Photonics ${ }^{\oplus}$ SP 1105 spectrophotometer. The wavelengths and the equations to calculate chlorophylls $a, b$, and carotenoids concentrations were based on the methodology described by Wellburn (1994).

\section{Experimental design and statistical analysis}

The experiment was arranged in a completely randomized design (CRD), in a $2 \times 5 \times 2$ factorial scheme (two cultivars, five light qualities and two types of sealing), totaling 20 treatments, with 10 replicates each. The experimental unit consisted of two plants per flask.

For the photosynthetic pigments analyzes three replicates were used, each one composed of a test tube containing three leaf discs. The data was submitted to Shapiro-Wilk's test and the growth parameters (root length, shoot length, number of green leaves, number of nodal segments, fresh weight, dry weight and number of senescent leaves) were transformed to $y=$ square root of $x+0.5$, to meet the normality assumptions (data is presented with nontransformed means). Data were submitted to analysis of variance by F-test and regression analysis for the quantitative data (days after inoculation). For qualitative data, the means were compared by the Tukey's test at 5\% 
significance level. All statistical analyzes were performed using the statistical program SISVAR (Ferreira 2011).

\section{RESULTS}

By the results of analysis of variance, root length, fresh weight and dry weight differed for the triple interaction among cultivars $x$ light qualities $x$ types of sealings. For the number of green leaves and number of nodal segments, there was a significant difference for cultivars $x$ types of sealings and for light qualities. For number of senescent leaves, there was a significant difference for light qualities and types of sealing. For shoot length, there was a significant difference only for the light qualities. For percentage of germination, there was difference only for light qualities $x$ types of sealing and for days after inoculation for both cultivars ('Espaguetinho' and 'Cayenne') $(p<0.05$, data not shown).

\section{Growth characters}

For percentage of germination in the 'Espaguetinho', it was possible to infer that the red LED with membrane was significantly higher than other light qualities, and no difference was observed in the type of sealing without porous membranes (Figure 1h; Figure 2a). For the 'Cayenne', there was a significant difference only for red/blue LEDs without porous membranes, where the highest percentage of germination was observed (Figure 2b; Figure 3e).

The red and red/blue LEDs were showed more senescent leaves compared to the blue LED (Figure 4a), and plants produced under these blue light conditions generated reduced amount of green leaves (Figure 4c). Also, plants grown without membrane have more senescent leaves than those cultivated in flasks with membranes (Figure 4b). The number of green leaves formed under red LEDs and red/blue LEDs was significantly higher as compared to white and blue LEDs and fluorescent lamps (Figure 4c). For cultivar $x$ types of sealing, the 'Espaguetinho' without membrane showed more leaves than with membrane, while the 'Cayenne'

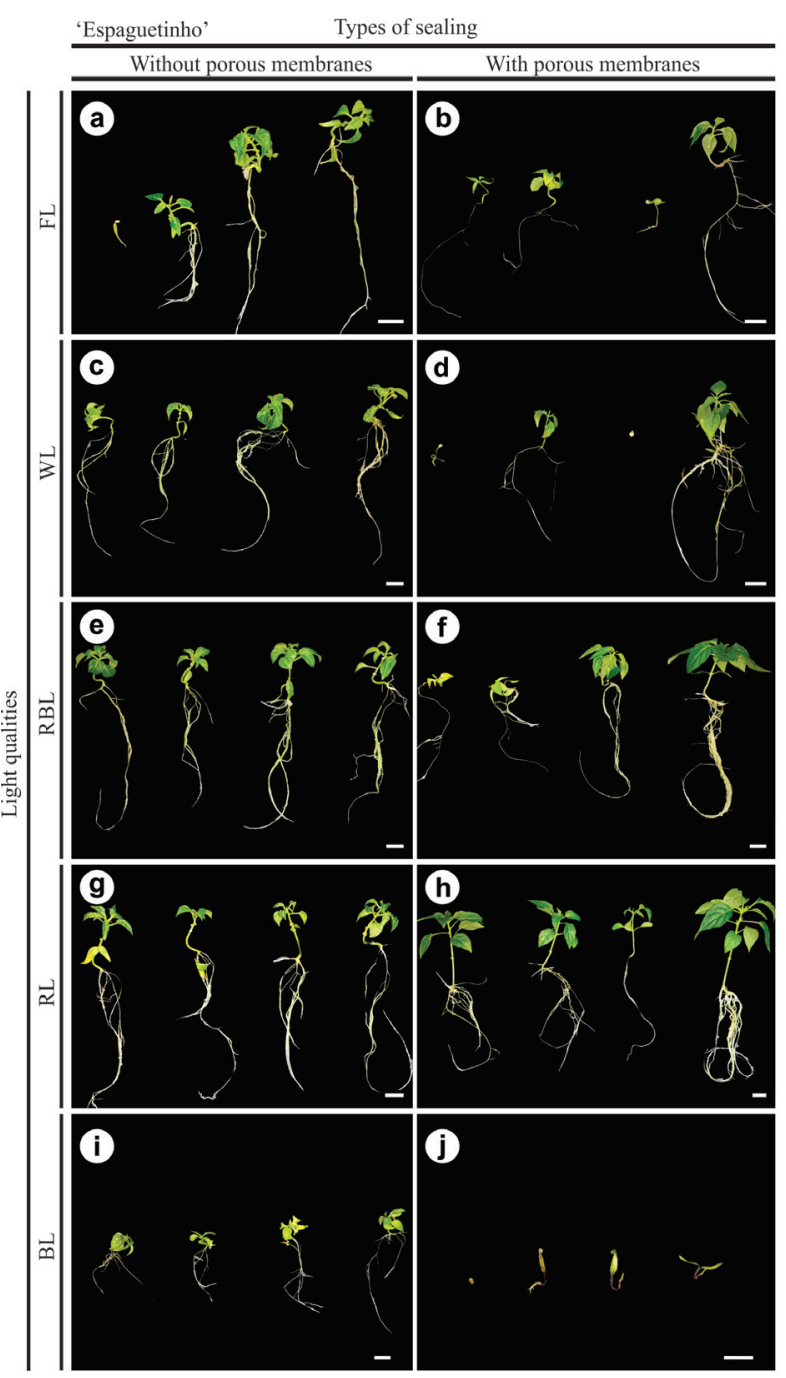

Figure 1. Plants of Capsicum frutescens cv.

'Espaguetinho' cultivated in vitro under different light qualities and types of sealing: Fluorescent $(\mathrm{FL})$ without (a) and with porous membranes (b); White LED (WL) without (c) and with porous membranes (d); Red/blue LED (RBL) without (e) and with porous membranes ( $f$ ); Blue LED (BL) without (g) and with porous membranes (h); Red LED (RL) without (i) and with porous membranes (j). Bars: $1 \mathrm{~cm}$. 
did not differed between the types of sealing. (Figure 4d).

The plants cultured in red/ blue LEDs showed greater number of nodal segments, despite did not differ statistically from white and red LEDs (Figure 5a). For cultivar $x$ types of sealing, plants grown in flasks without membrane had more nodal segments than those with membrane for 'Espaguetinho' and for 'Cayenne', the types of sealing were similar for this feature. 'Cayenne' had more nodal segments than 'Espaguetinho' in the treatments with membrane while without membrane there was no difference between the cultivars (Figure 5b).
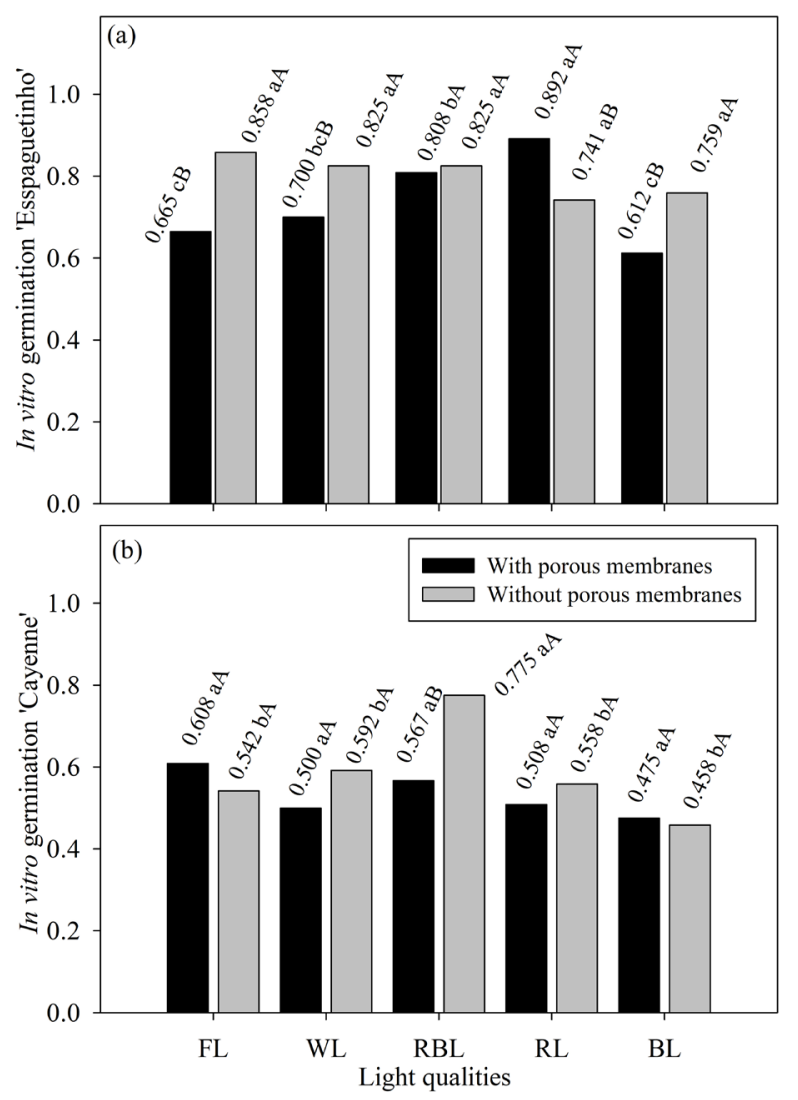

Figure 2. In vitro germination of Capsicum frutescens cv. Espaguetinho (a) and Cayenne (b), evaluated after 42 days of culture under different light qualities and types of sealing. *Lowercase letters in type of sealing (with or without membrane), and uppercase letters in the same light quality do not differ by the Tukey's test at $5 \%$ level.
Plants cultured in red LEDs developed longer shoots, followed by those grown under red/blue LEDs (Figures 1; 3; 5c). For root length, there was a triple interaction among the factors. Considering cultivar $\mathrm{x}$ light qualities $\mathrm{x}$ types of sealing between the 'Espaguetinho' and 'Cayenne' in the white LED, the former without membrane differed statistically from the one with membrane, with greater root length, whereas the later did not differed. 'Espaguetinho' under blue LEDs and without membrane was superior from the one with membrane, while to 'Cayenne' they did not differed (Table I).

'Espaguetinho' plants grown under red LEDs in with membranes developed longer roots than those cultured in other light qualities. For the treatments without membrane, there was no significant difference between the light qualities instead. For 'Cayenne' with membrane, the lights fluorescent, and white, red/blue and red LEDs had longer roots than those grown under blue LEDs, the same occurred for the treatment without membrane in this cultivar. The comparisons among the lights red/blue, red and blue LEDs did not varied in root length between the cultivars, just as for the types of sealing in red/blue, red and blue LEDs (Table I; Figures $1 e, 1 f, 1 g, 1 h, 1 i, 1 j$ and $3 e, 3 f, 3 g, 3 h, 3 i, 3 j)$.

For fresh weight there was also a triple interaction among the treatments and both cultivars did not differ when analyzed in the fluorescent lamp and blue LED. However, 'Espaguetinho' without membrane differed from the one with membrane with greater fresh weight, while 'Cayenne' did not differ. For both cultivars, the treatment without membrane was superior from the one with membrane in the red/blue LED. In the red LED, 'Espaguetinho' did not present any significant difference. Unlike, for 'Cayenne' the treatment without membrane produced plants with greater fresh weight (Table II). 
For light qualities $x$ cultivar $x$ types of sealing, the 'Espaguetinho' under the red LED was superior only from the white and blue LED in the type of sealing with membrane, while in the treatment without membrane, the red/blue LED was superior only from the fluorescent lamp and blue LED. Within 'Cayenne' with membrane, the light qualities did not show statistical

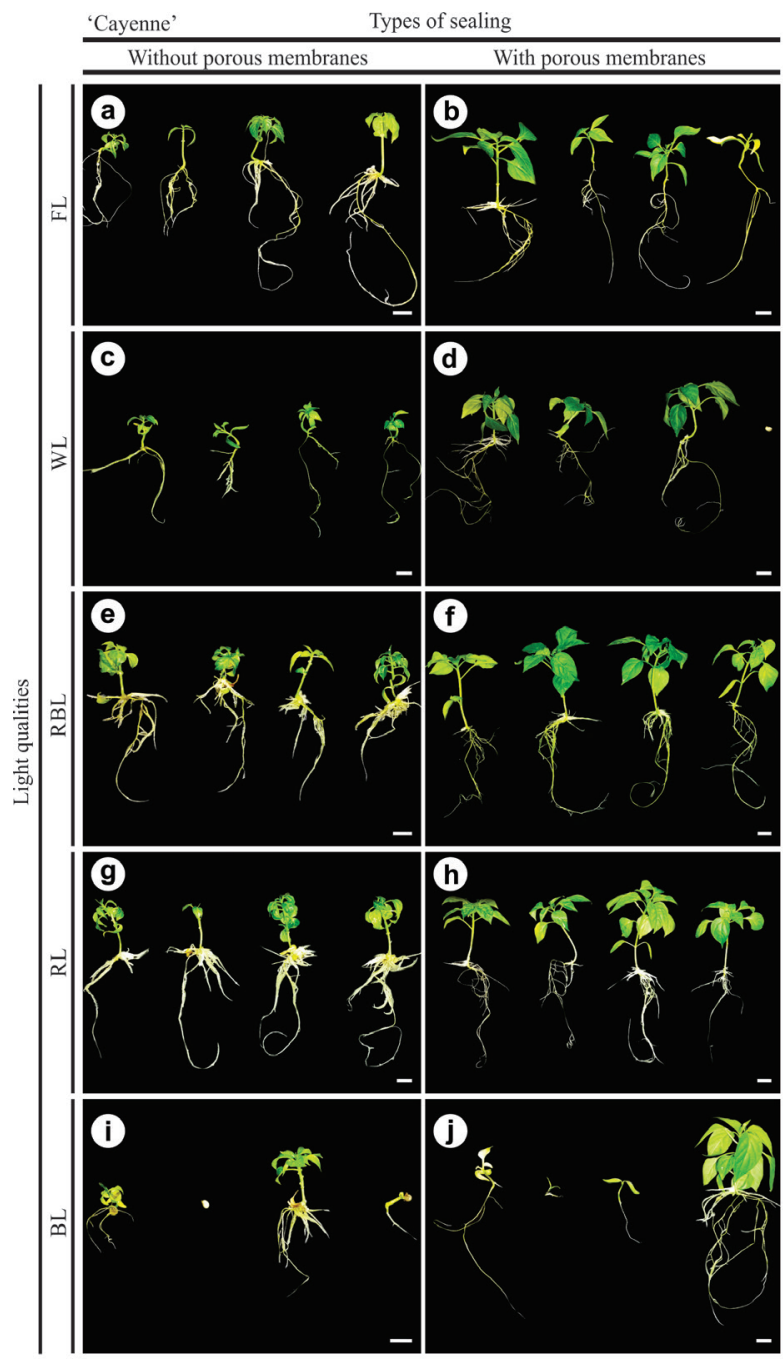

Figure 3. Plants of Capsicum frutescens cv. 'Cayenne' cultivated in vitro under different light qualities and types of sealing: Fluorescent (FL) without (a) and with porous membranes (b); White LED (WL) without (c) and with porous membranes (d); Red/blue LED (RBL) without (e) and with porous membranes ( $f$ ); Blue LED (BL) without (g) and with porous membranes (h); Red LED (RL) without (i) and with porous membranes (j). Bars: $1 \mathrm{~cm}$. difference among the treatments; and for the treatment without membrane, the red/blue LED produced plants with greater fresh weight than all the other light qualities (Table II). When compared to membrane treatment between the two cultivars, there was no significant difference among the treatments in the light qualities. For the treatment without membrane, 'Cayenne' was superior from 'Espaguetinho' in the red/blue LED and red LED, while the other treatments did not differ among themselves (Table II).

For dry weight there was also a triple interaction. Thus, considering cultivar $x$ light qualities $x$ types of sealing, 'Espaguetinho' did not differ statistically, and the 'Cayenne' without membrane was superior when compared to the one with membrane with red/blue and red LEDs, while the other treatments did not differ for this cultivar. For light qualities $x$ cultivar $x$ types of sealing in the 'Espaguetinho' there was no difference among the light qualities; the 'Cayenne' in the treatment without membrane and red/blue LED produced plant with dry weight greater than all the other light qualities; while in the treatment with membrane for this cultivar there was no difference among the light qualities (Table III).

Considering the types of sealing $x$ cultivar $x$ light qualities, only the treatment with membrane and red LEDs differed statistically between the cultivars, showing higher values for dry weight, while in the treatment without membrane in the white LED, and 'Espaguetinho' was superior; in red/blue LED for 'Cayenne' the treatment without membrane was higher. For the other treatments in the cultivar Cayenne, the types of sealing did not differ statistically (Table III).

\section{Photosynthetic pigments}

By the analysis of variance, the chlorophyll $b$ differed for the triple interaction between cultivars $x$ light qualities $x$ types of sealing. For the chlorophyll $a$, there was a significant difference for cultivar $\mathrm{x}$ light qualities and types 
of sealing $x$ light qualities. For carotenoids a significant difference was evidenced between cultivar x light qualities.

For chlorophyll a only 'Cayenne' in the blue LED was significantly higher compared to 'Espaguetinho' $(p<0.05)$. Light qualities within the cultivar, for 'Espaguetinho', the blue LED showed inferior results compared to the other light qualities, without differences for 'Cayenne' $(p<0.05)$ (Figure 6a). Still, for chlorophyll $a$, considering types of sealing within the light qualities, the treatment with membrane was superior compared to the treatment without membrane, only in the red/blue LED. For light qualities $x$ types of sealing, the blue LED treatment was inferior to the other light qualities within the membrane treatment, while within the treatment without membrane, the light qualities fluorescent and white LED were superior to the others (Figure 6b).

For 'Espaguetinho', cultivar x light qualities factorial was superior to 'Cayenne' for carotenoids only in red/blue and red LEDs. And for light qualities within the cultivar, plants grown under blue LEDs had less carotenoids than the other treatments in the 'Espaguetinho', while in the 'Cayenne' cultivar there was no significant difference among the light qualities (Figure 6c).

For the variable chlorophyll $b$, considering cultivar $x$ light quality $x$ types of sealing, the cultivar 'Espaguetinho', only the white LED treatment without membrane differed from the one with membrane; for 'Cayenne' there was no significant difference between types of sealing. In the types of sealing $x$ cultivar $x$ light qualities
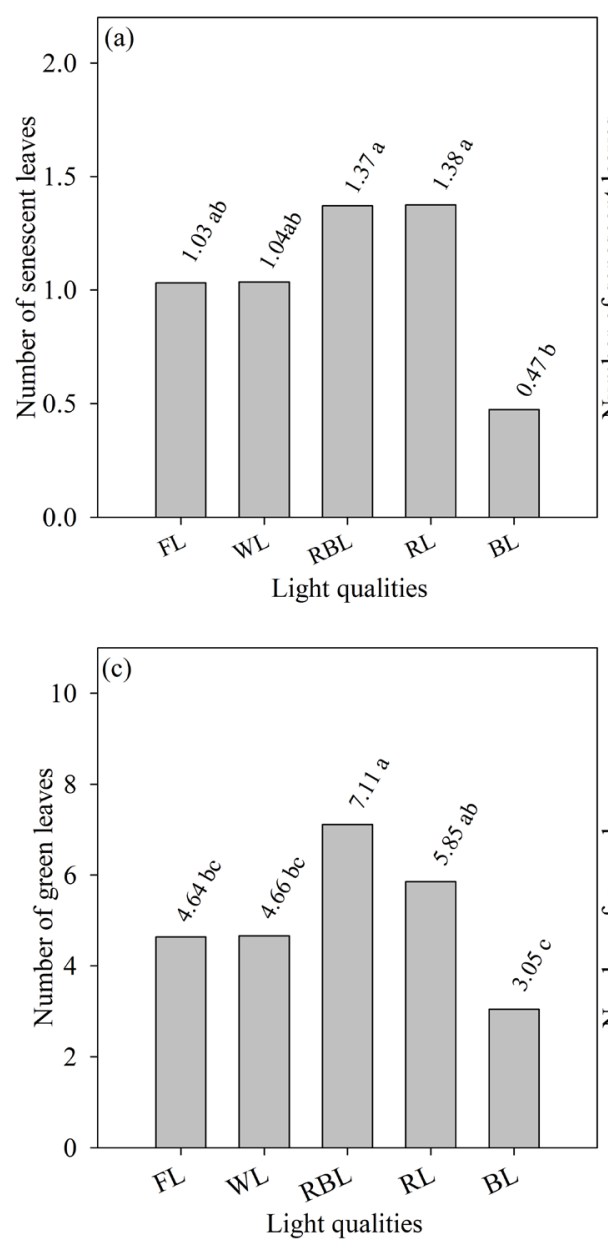
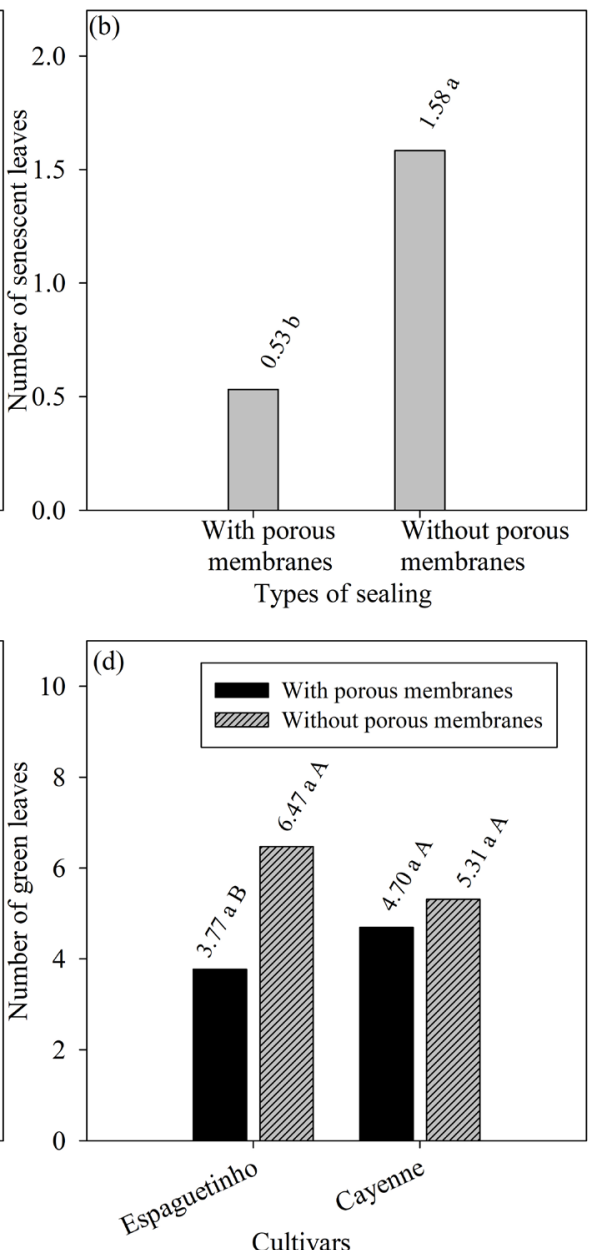

Figure 4. Growth variables of Capsicum frutescens cv. Cayenne and Espaguetinho, cultivated under different light qualities and types of sealing. Number of senescent leaves for the factor light qualities (a) and for the factor types of sealing (b); Number of green leaves for the factor light qualities (c) and for the interaction types of sealing and cultivars (d).* Equal letters (figures a-c), do not differ by Tukey's test, $5 \%$ level; and lowercase letters equal in the same type of sealing (with or without membrane) and uppercase letters for the same cultivar ('Espaguetinho' or 'Cayenne') (figure d) do not differ from each other by the Tukey's test at $5 \%$ level. 


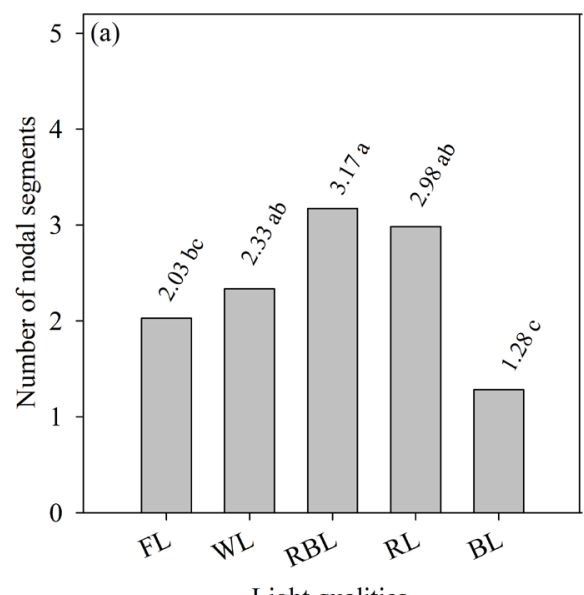

Light qualities

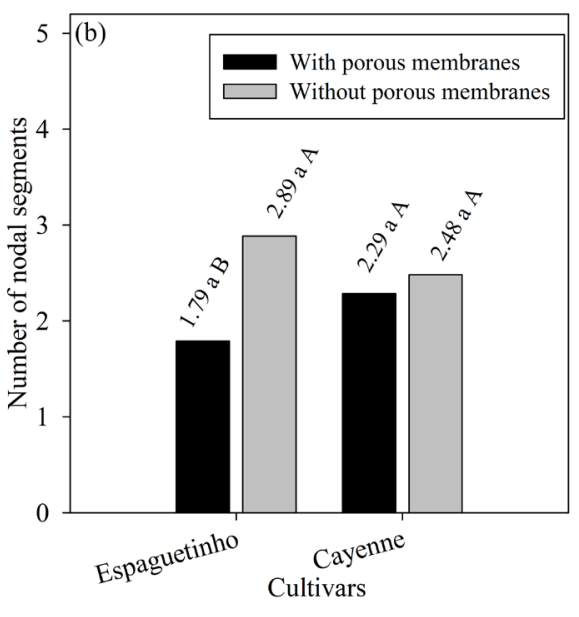

Cultivars

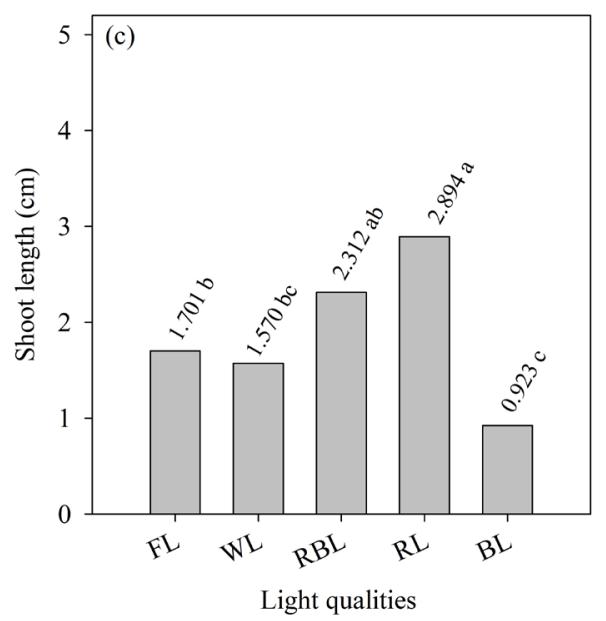

Figure 5. Growth variables of Capsicum frutescens cv. Cayenne and Espaguetinho cultivated under different light qualities and types of sealing. Number of nodal segments for the factor light qualities (a) and for the interaction types of sealing and cultivars (b); and shoot length for the light qualities factor (c). * Lowercase letters for light quality do not differ by Tukey's test, $5 \%$ level $(\mathrm{a}-\mathrm{c})$; Lowercase letters in the same type of sealing (with or without membranes) do not differ the cultivars between them, and uppercase letters in each cultivar do not differ for the type of sealing, by Tukey's test, $5 \%$ level (b).

Table I. Root length of Capsicum frutescens cultivars ('Espaguetinho' and 'Cayenne') cultivated under different light qualities and types of sealing.

\begin{tabular}{|c|c|c|c|c|c|}
\hline & \multicolumn{2}{|c|}{ cv. Espaguetinho } & & \multicolumn{2}{|c|}{ cv. Cayenne } \\
\hline & $\begin{array}{l}\text { With porous } \\
\text { membranes }\end{array}$ & $\begin{array}{l}\text { Without porous } \\
\text { membranes }\end{array}$ & & $\begin{array}{l}\text { With porous } \\
\text { membranes }\end{array}$ & $\begin{array}{c}\text { Without porous } \\
\text { membranes }\end{array}$ \\
\hline Light qualities & \multicolumn{5}{|c|}{ Root length $(\mathrm{cm})$} \\
\hline Fluorescent lamp & $2.98 \mathrm{aB} \beta$ & $4.16 \mathrm{aA} \alpha$ & & $5.94 \mathrm{aA} \alpha$ & $4,30 \mathrm{aAB} \alpha$ \\
\hline White LED & $1.33 \mathrm{bB} \beta$ & $5.35 \mathrm{aA} \alpha$ & & $5.24 \mathrm{aAB} \alpha$ & $3.69 \mathrm{aAB} \alpha$ \\
\hline Red/blue LED & $4.34 \mathrm{aB} \alpha$ & $5.50 \mathrm{aA} \alpha$ & & $6.92 \mathrm{aA} \alpha$ & $4.88 \mathrm{aAB} \alpha$ \\
\hline Red LED & $9.55 \mathrm{aA} \alpha$ & $4.38 \mathrm{bA} \alpha$ & & $8.08 \mathrm{aA} \alpha$ & $6.73 \mathrm{aA} \alpha$ \\
\hline Blue LED & $0.49 \mathrm{bB} \alpha$ & $3.93 a A \alpha$ & & $1.71 \mathrm{aBa}$ & $2.01 \mathrm{aB} \alpha$ \\
\hline CV (\%) & & & 37.41 & & \\
\hline
\end{tabular}

* Lowercase letters are equal in cultivars within each level of light qualities and types of sealing; uppercase letters are equal in light qualities within each level of cultivars and types of sealing; and Greek letters are equal in types of sealing within each level of cultivars and light qualities by Tukey's test, at $5 \%$ level. 
Table II. Fresh weight of Capsicum frutescens cultivars ('Espaguetinho' and 'Cayenne') cultivated under different light qualities and types of sealing.

\begin{tabular}{|c|c|c|c|c|c|}
\hline & \multicolumn{2}{|c|}{ cv. Espaguetinho } & & \multicolumn{2}{|c|}{ cv. Cayenne } \\
\hline & $\begin{array}{l}\text { With porous } \\
\text { membranes }\end{array}$ & $\begin{array}{c}\text { Without porous } \\
\text { membranes }\end{array}$ & & $\begin{array}{l}\text { With porous } \\
\text { membranes }\end{array}$ & $\begin{array}{l}\text { Without porous } \\
\text { membranes }\end{array}$ \\
\hline Light qualities & \multicolumn{5}{|c|}{ Fresh weight (g) } \\
\hline Fluorescent lamp & $0.036 \mathrm{aAB} \alpha$ & $0.106 \mathrm{aB} \alpha$ & & $0.134 \mathrm{aA} \alpha$ & $0.092 \mathrm{aB} \alpha$ \\
\hline White LED & $0.021 \mathrm{bB} \alpha$ & 0.189 aAB $\alpha$ & & $0.109 \mathrm{aA} \alpha$ & $0.107 \mathrm{aB} \alpha$ \\
\hline Red/blue LED & $0.126 \mathrm{bAB} \alpha$ & $0.284 \mathrm{aA} \beta$ & & $0.180 \mathrm{bA} \alpha$ & $0.436 \mathrm{aA} \alpha$ \\
\hline Red LED & $0.198 \mathrm{aA} \alpha$ & $0.111 \mathrm{aAB} \beta$ & & $0.114 \mathrm{bA} \alpha$ & $0.254 \mathrm{aB} \alpha$ \\
\hline Blue LED & $0.093 \mathrm{aB} \alpha$ & $0.099 \mathrm{aB} \alpha$ & & $0.037 \mathrm{aA} \alpha$ & $0.099 \mathrm{aB} \alpha$ \\
\hline CV (\%) & & & 10.18 & & \\
\hline
\end{tabular}

* Lowercase letters are equal in cultivars within each level of light qualities and types of sealing; uppercase letters are equal in light qualities within each level of cultivars and types of sealing; and Greek letters are equal in types of sealing within each level of cultivars and light qualities by Tukey's test, at $5 \%$ level.

Table III. Dry weight of Capsicum frutescens cultivars ('Espaguetinho' and 'Cayenne') cultivated under different light qualities and types of sealing.

\begin{tabular}{|c|c|c|c|c|c|}
\hline & \multicolumn{2}{|c|}{ cv. Espaguetinho } & & \multicolumn{2}{|c|}{ cv. Cayenne } \\
\hline & $\begin{array}{l}\text { With porous } \\
\text { membranes }\end{array}$ & $\begin{array}{l}\text { Without porous } \\
\text { membranes }\end{array}$ & & $\begin{array}{l}\text { With porous } \\
\text { membranes }\end{array}$ & $\begin{array}{c}\text { Without porous } \\
\text { membranes }\end{array}$ \\
\hline Light qualities & \multicolumn{5}{|c|}{ Dry weight (g) } \\
\hline Fluorescent lamp & $0.010 \mathrm{aA} \alpha$ & $0.010 \mathrm{aA} \alpha$ & & $0.011 \mathrm{aA} \alpha$ & $0.014 \mathrm{aB} \alpha$ \\
\hline white LED & $0.010 \mathrm{aA} \alpha$ & $0.018 \mathrm{aA} \alpha$ & & $0.011 \mathrm{aA} \alpha$ & $0.010 \mathrm{aB} \beta$ \\
\hline Red/blue LED & $0.014 \mathrm{aA} \alpha$ & 0.018 aA & & $0.012 \mathrm{bA} \alpha$ & $0.029 \mathrm{aA} \alpha$ \\
\hline Red LED & $0.016 \mathrm{aA} \alpha$ & $0.013 \mathrm{aA} \alpha$ & & $0.004 \mathrm{bA \beta}$ & $0.016 \mathrm{aB} \alpha$ \\
\hline Blue LED & $0.006 \mathrm{aA} \alpha$ & $0.001 \mathrm{aA} \alpha$ & & $0.005 \mathrm{aA} \alpha$ & $0.012 \mathrm{aB} \alpha$ \\
\hline CV (\%) & & & 0.89 & & \\
\hline
\end{tabular}

*Lowercase letters are equal in cultivars within each level of light qualities and types of sealing; uppercase letters are equal in light qualities within each level of cultivars and types of sealing; and Greek letters are equal in types of sealing within each level of cultivars and light qualities by Tukey's test, at $5 \%$ level. 

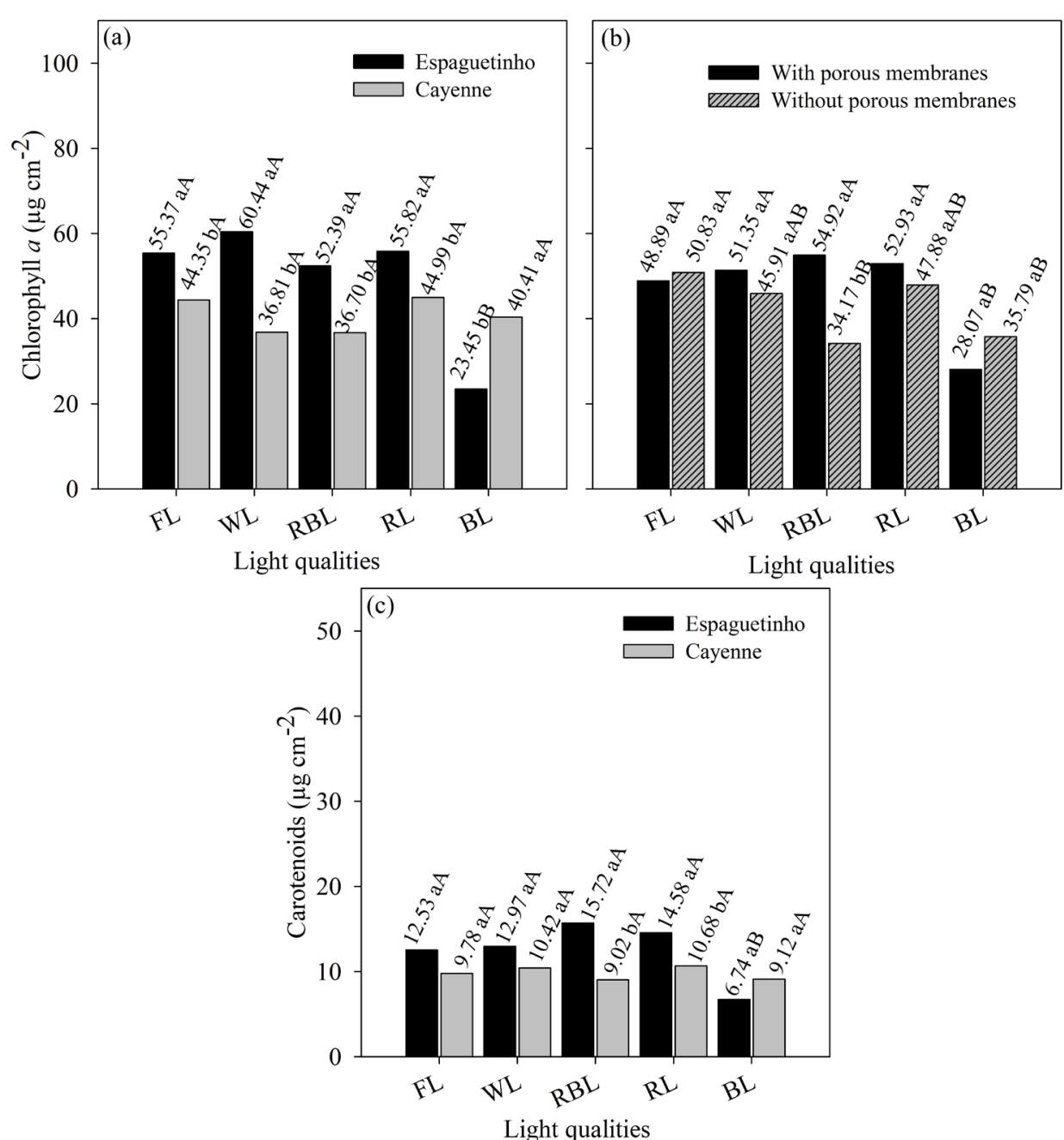

Figure 6. Photosynthetic pigments of Capsicum frutescens cv. Espaguetinho and Cayenne, cultivated under different light qualities and types of sealing. Chlorophyll a for the two cultivars in different light qualities (a); chlorophyll a for both types of sealing in different light qualities (b); Carotenoids for two cultivars in different light qualities (c). *Lowercase letters for the same cultivar and uppercase letters in the same light quality do not differ the cultivars from each other, by Tukey's test at $5 \%$ level ( $a$ and $c)$. Lowercase letters for the same type of sealing and uppercase letters in the same light quality do not differ for the types of sealing, by Tukey's test, $5 \%$ level (b).

Table IV. Chlorophyll $b$ contents of Capsicum frutescens cultivars ('Espaguetinho' and 'Cayenne') cultivated under different light qualities and types of sealing.

\begin{tabular}{|c|c|c|c|c|c|}
\hline & \multicolumn{2}{|c|}{ cv. 'Espaguetinho' } & & \multicolumn{2}{|c|}{ cv. 'Cayenne' } \\
\hline & $\begin{array}{l}\text { With porous } \\
\text { membranes }\end{array}$ & $\begin{array}{c}\text { Without porous } \\
\text { membranes }\end{array}$ & & $\begin{array}{l}\text { With porous } \\
\text { membranes }\end{array}$ & $\begin{array}{l}\text { Without porous } \\
\text { membranes }\end{array}$ \\
\hline Light qualities & \multicolumn{5}{|c|}{ Chlorophyll b ( $\left.\mu \mathrm{g} \mathrm{cm}^{-2}\right)$} \\
\hline Fluorescent lamps & $18.2585 \mathrm{aA} \alpha$ & $18.6498 \mathrm{aB} \alpha$ & & $13.8718 \mathrm{aA} \alpha$ & $9.5292 \mathrm{aA} \alpha$ \\
\hline White LED & $6.8423 \mathrm{bA} \alpha$ & $36.7971 \mathrm{aA} \alpha$ & & $10.0560 \mathrm{aA} \alpha$ & $6.0149 \mathrm{aA} \beta$ \\
\hline Red/blue LED & $11.0967 \mathrm{aA} \alpha$ & $9.5425 \mathrm{aB} \alpha$ & & $8.2965 \mathrm{aA} \alpha$ & $3.7168 \mathrm{aA} \alpha$ \\
\hline Red LED & $10.1240 \mathrm{aA} \alpha$ & $7.8317 \mathrm{aB} \alpha$ & & $7.1692 \mathrm{aA} \alpha$ & $4.7372 \mathrm{aA} \alpha$ \\
\hline Blue LED & $4.2678 \mathrm{aA} \alpha$ & $8.5907 \mathrm{aB} \alpha$ & & $8.4236 \mathrm{aA} \alpha$ & $8.3783 \mathrm{aA} \alpha$ \\
\hline CV (\%) & & & 20.83 & & \\
\hline
\end{tabular}

*Lowercase letters are equal in cultivars within each level of light qualities and types of sealing; uppercase letters are equal in light qualities within each level of cultivars and types of sealing; and Greek letters are equal in types of sealing within each level of cultivars and light qualities by Tukey's test, at $5 \%$ level. 
among the cultivars in the treatment with membrane, there was no significant difference between the light qualities; in the treatment without membrane only the white LED was superior in 'Espaguetinho', differing significantly from'Cayenne'(Table IV).

\section{DISCUSSION}

This work describes in vitro germination, growth and development of Capsicum frutescens using different light qualities and gas permeable membranes. The use of gas-permeable membranes associated with red and red/ blue LEDs, resulted in plants with significant differences in growth and morphophysiological parameters (Figures 1f, 1h, 3f, 3h, 4, 5 and 6). The germination and development of different species are affected by intrinsic characteristics of seeds or environmental factors such as light quality (Victório \& Lage 2009); and, in this case, the red-light spectrum stimulates seed germination of several species (Figure $3 \mathrm{~g}$ and $3 \mathrm{~h}$ ). Similar results were observed in the present work, in which the red LED with porous membrane presented greater percentage of germination for the cultivar 'Espaguetinho', and the red/blue LED without membrane for the 'Cayenne' cultivar (Figures $1 \mathrm{~h}$ and 3h).

In this study, the use of porous membranes remarkably reduced the number of senescent leaves, a constraint in tissue culture systems due to either ethylene accumulation or the low nutrients absorption from the medium due low transpiration rates. Leaf abscission is a challenge for in vitro cultivation due to the accumulation of ethylene inside the culture environment and low gas exchange, which can generate physiological anomalies in the plants. Gas-permeable membranes have been used to provide the maintenance of $\mathrm{CO}_{2}$ concentration, stimulate photosynthesis, lessen or inhibit the negative effects of this ethylene, reduce the relative humidity, increase the transpiration and absorption of water and nutrients, stimulating the photoautotrophic development of plants in vitro (Rodrigues et al. 2011, Xiao et al. 2011). These gas exchanges allow ethylene releasing, which reduce the effect of leaf senescence (Rodrigues et al. 2011). This was also observed in this study when porous membranes were used (Figure $4 \mathrm{a}$ and $4 b)$.

The progress of leaf senescence is influenced by physical and/or chemical factors in the growth conditions (e.g. temperature, precipitation and radiation). There are reports claiming that the plant regulates internal factors such as oxidative status and sugar levels to control senescence (Eldeen \& Elgimabi 2017). Causin et al. (2006) observed that light quality affected oxidative metabolism in wheat leaves and senescence was delayed under blue light. In our work the blue light quality reduced leaf senescence in both cultivars (Figure 4a) however, plants produced under these conditions generated a reduced amount of green leaves (Figure 1i, 1j, 3i, 3j and 4c).

Plants are dependent on processes that involve the action of photoreceptors, which control plant development phases and are highly responsive to changes in light quality (Jensen et al. 2018, Braga et al. 2009). Wavelengths between 400 and $700 \mathrm{~nm}$ are required for the photosynthesis. These spectra were found in blue and red LED lamps, causing an increase in chlorophyll and carotenoids (Yeh \& Chung 2009). In studies with Lilium sp., cultivar Pesarounder, red/blue LEDs promoted greater fresh and dry weight compared to fluorescent lamps (Lian et al. 2002). Rocha et al. (2010) also reported promising results on the use of red LEDs in photosynthetic pigment contents and a higher number of shoots in Fragaria x Ananassa plants cultured in vitro. These results corroborate with 
the present work, demonstrating the superiority and efficiency of red/blue and blue LEDs for fresh and dry weight and photosynthetic pigments for both cultivars analyzed.

Regarding the photosynthetic pigments, Saldanha et al. (2012) observed an increase when plants of Pfaffia glomerata were cultivated in flasks with porous membranes. Likewise, in the present work, the use of porous membranes associated with red/blue LEDs favored the increase of total chlorophyll content (Figure $6 \mathrm{a}$ and $6 \mathrm{~b}$ ). Red LED also promoted a greater increase in chlorophyll content in Ocimun basilicum (Ahlman et al. 2017). Chlorophyll molecules absorb blue and red wavelengths more efficiently since they correspond to the light absorption spectra of chlorophyll and carotenoids, which improves the photosynthetic metabolism with characteristics associated to autotrophic growth in plants (Yeh \& Chung 2009).

In this study, the red LED provided an increase in root length (Table I, Figures 1g, 1h, 3g, and 3h). Hung et al. (2016) also observed that red light was better for in vitro rooting of Vaccinium corymbosum. The recognition of light qualities by plants occurs by the phytochrome. The different light spectra increase active forms of phytochrome, inducing rooting (Godoi \& Takaki 2005, Victório \& Lage 2009). In fact, Pawłowska et al. (2018) observed that the red LED resulted in the formation of numerous adventitious roots with short lengths, which is beneficial during the transfer to ex vitro conditions.

As in the present work (Figure 5c), also observed a reduction in the growth of tomato seedlings cultivated under blue LED light compared to those cultivated under other light qualities. Pawłowska et al. (2018) also observed that the blue light strongly suppressed the growth of Gerbera jamesonii, causing a significant length reduction and shortening of petioles. This characteristic is related to the inhibition of hypocotyl elongation, caused by cryptochrome signaling, due to the increased of blue light absorption by the phototropin in hypocotyl cells (Folta \& Edgar 2001).

This work is the first report on the influence of light quality and sealing type in the in vitro germination, growth and development of two Capsicum frutescens cultivars. The use of porous membranes in the culture flasks is important to face frequent problems in conventional tissue culture such as leaf senescence. In general, the light quality provided by red and red/ blue LEDs substantially improved the growth and development parameters of produced in vitro plants, which are superior to those cultured in fluorescent lamps commonly used in conventional cultivation, demonstrating that LEDs may be advantageous substituent in the cultivation of plants in vitro. Despite the cultivar 'Espaguetinho' showed higher chlorophyll a content than 'Cayenne', in general there were no differences in morphogenic responses between these cultivars, showing that the recommendations of in vitro culture conditions can be standardized for the two genotypes. Furthermore, the present study provides a basis for future researches and applications to anticipate the productive cycle of Capsicum frutescens under ex vitro conditions.

\section{Acknowledgments}

The authors would like to thank the research funding agency CAPES (Coordenação de Aperfeiçoamento de Pessoal de Nivel Superior) for the scholarships granted to the post-graduate students participating in the study.

\section{REFERENCES}

AGUILAR LMG. 2016. Estabelecimiento de un protocolo para la incucción de la androgénesis en Capsicum chinense Jacq. (Master of Science) Or Tesis, Centro de Investigación Cientifica de Yucatán, A. C. 
AHLMAN L, BÅNKESTAD D \& WIK T. 2017. Using chlorophyll a fluorescence gains to optimize LED light spectrum for short term photosynthesis. Comput Electron Agric 142: 224-234. doi: 10.1016/j.compag.2017.07.023.

ARAGÓN C, CARVALHO L, GONZÁLEZ J, ESCALONA M \& AMÂNCIO S. 2010. Ex vitro acclimatization of plantain plantlets micropropagated in temporary immersion bioreactor. Biol Plant 54: 237-244. doi:10.1007/s10535-010-0042-y.

BANTIS F, OUZOUNIS T \& RADOGLOU K. 2016. Artificial LED lighting enhances growth characteristics and total phenolic content of Ocimum basilicum, but variably affects transplant success. Sci Hortic 198: 277-283. doi:http://dx.doi.org/10.1016/j.scienta.2015.11.014.

BATISTA DS, DIAS LLC, MACEDO AF, RÊGO MM, RÊGO ER, FLOH EIS, FINGER FL \& OTONI WC. 2013. Suppression of ethylene levels promotes morphogenesis in pepper (Capsicum annuum L.). In Vitro Cell Dev Biol Plant 49: 759-764. doi: 10.1007/s11627-013-9559-z.

BATISTA DS, DIAS LLC, RÊGO MM, SALDANHA CW \& OTONI WC. 2017. Flask sealing on in vitro seed germination and morphogenesis of two types of ornamental pepper explants. Cienc Rural 47:e20150245. doi:10.1590/0103-8478cr20150245.

BATISTA DS ET AL. 2018. Light quality in plant tissue culture: does it matter? In Vitro Cell Dev Biol Plant 54:195-215. doi: 10.1007/s11627-018-9902-5.

BRAGA FT, PASQUAL M, DE CASTRO EM, DIGNART SL, BIAGIOTTI G \& PORTO JMP. 2009. Qualidade de luz no cultivo in vitro de Dendranthema grandiflorum cv. Rage: Características morfofisiológicas. Ciênc Agrotec 33: 502-508. doi: 10.1590/ S1413-/70542009000200022.

CARVALHO RF, TAKAKI M \& AZEVEDO RA. 2011. Plant pigments: The many faces of light perception. Acta Physiol Plant 33: 241-248. doi: 10.1007/s11738-010-0533-7.

CAUSIN HF, JAUREGUI RN \& BARNEIX AJ. 2006. The effect of light spectral quality on leaf senescence and oxidative stress in wheat. Plant Sci 171: 24-33. doi: 10.1016/j. plantsci.2006.02.009.

CHANDRA S, BANDOPADHYAY R, KUMAR V \& CHANDRA R. 2010. Acclimatization of tissue cultured plantlets: from laboratory to land. Biotechnol Lett 32: 1199-1205. doi: 10.1007/s10529-010-0290-0.

DABAUZA M \& PEÑA L. 2001. High efficiency organogenesis in sweet pepper (Capsicum annuum L.) tissues from different seedling explants. Plant Growth Regul 33: 221229. doi:10.1023/A:1017585407870.

DAVIS CB, MARKEY CE, BUSCH MA \& BUSCH KW. 2007. Determination of capsaicinoids in Habanero peppers by chemometric analysis of UV spectral data. J Agric Food Chem 55: 5925-5933. doi: 10.1021/jf0704413k.

ELDEEN M \& ELGIMABI NE. 2017. Effect of light irradiance on regulation of leaf senescence. J Bot Sci 6: 5-13. doi: openaccess/effect-of-light-irradiance-on-regulation-of-leafsenescence-.pdf.

FERREIRA DF. 2011 Sisvar: a computer statistical analysis system. Ciênc Agrotec 35: 1039-1042. doi:10.1590/ S1413-70542011000600001.

FOLTA KM \& EDGAR EP. 2001. Unexpected roles for cryptochrome 2 and phototropin revealed by high-resolution analysis of blue light-mediated hypocotyl growth inhibition. Plant J 26: 471-478. doi: 10.1046/j.1365-313x.2001.01038.x.

GAMMOUDI N, PEDRO TS, FERCHICHI A \& GISBERT C. 2018. Improvement of regeneration in pepper: a recalcitrant species. In Vitro Cell Dev Biol Plant 54(2): 145-153. doi:10.1007/s11627-017-9838-1.

GARRUÑA-HERNÁNDEZ R, MONFORTE-GONZÁLEZ M, CANTOAGUILAR A, VÁZQUEZ-FLOTA F \& ORELLANA R. 2013. Enrichment of carbon dioxide in the atmosphere increases the capsaicinoids content in Habanero peppers (Capsicum chinense Jacq.). J Sci Food Agric 93: 1385-1388. doi:10.1002/ jsfa.5904.

GODOI S \& TAKAKI M. 2005. Efeito da temperatura e a participação do fitocromo no controle dagerminação de sementes de embaúba. Rev Bras Sementes 27: 87-90. doi: pdf/rbs/v27n2/a13v27n2.pdf.

HUNG CD, HONG C-H, KIM S-K, LEE K-H, PARK J-Y, NAM M-W, CHOI D-H \& LEE H-I. 2016. LED light for in vitro and ex vitro efficient growth of economically important highbush blueberry (Vaccinium corymbosum L.). Acta Physiol Plant 38: 152. doi: 10.1007/s11738-016-2164-0.

JENSEN NB, CLAUSEN MR \& KJAER KH. 2018. Spectral quality of supplemental LED grow light permanently alters stomatal functioning and chilling tolerance in basil (Ocimum basilicum L.). Sci Hortic 227: 38-47. doi: 10.1016/j. scienta.2017.09.011.

KOTHARI SL, JOSHI A, KACHHWAHA S \& OCHOA-ALEJO N. 2010. Chilli peppers - A review on tissue culture and transgenesis. Biotechnol Adv 28: 35-48. doi: https://doi. org/10.1016/j.biotechadv.2009.08.005.

KOZAI T. 2010. Photoautotrophic micropropagationenvironmental control for promoting photosynthesis. Propag Ornam Plants 10: 188-204.

KOZAI T \& KUBOTA C. 2001. Developing a photoautotrophic micropropagation system for woody plants. J Plant Res 114: 525-537. doi: 10.1007/PL00014020. 
LIAN M-L, MURTHY HN \& PAEK K-Y. 2002. Effects of light emitting diodes (LEDS) on the in vitro induction and growth of bulblets of Lilium oriental hybrid 'Pesaro'. Sci Hortic 94: 365-370. doi: 10.1016/S0304-4238(01)00385-5.

MOHAMED MAH \& ALSADON AA. 2011. Effect of vessel type and growth regulators on micropropagation of Capsicum annuum. Biol Plant 55: 370-374. doi:10.1007/ s10535-011-0057-Z.

MORELLI G \& RUBERTI I. 2000. Shade avoidance responses. Driving auxin along lateral outes. Plant Physiol 122: 621626. doi: http://www.jstor.org/stable/4279136.

MUELleR-SeITZ E, HIEPLER C \& PETZ M. 2008. Chili Pepper fruits: Content and pattern of capsaicinoids in single fruits of different ages. J Agric Food Chem 56: 12114-12121. doi: 10.1021/jf802385v.

MULEO R, MORINI S \& CASANO S. 2001. Photoregulation of growth and branching of plum shoots: Physiological action of two photosystems. In Vitro Cell Dev Biol Plant 37: 609-617. doi: https://doi.org/10.1007/s11627-001-0107-X.

MURASHIGE T \& SKOOG F. 1962. A revised medium for a rapid growth and bioassays with tobacco tissues cultures. Physiol Plant 15: 473-479. doi: 10.1111/j.1399-3054.1962. tb08052.x.

NGUYEN QT, XIAO Y \& KOZAI T. 2016. Photoautotrophic micropropagation. In: Kozai T, Niu G and Takagaki M (Eds). Plant factory. Academic Press: Burlington, p. 271-283.

OCHOA-ALEJO N \& RAMIREZ-MALAGON R. 2001. In vitro chili pepper biotechnology. In Vitro Cell Dev Biol Plant 37: 701729. doi:10.1007/s11627-001-0121-z.

PAWŁOWSKA B, ŻUPNIK M, SZEWCZYK-TARANEK B \& CIOĆ M. 2018. Impact of LED light sources on morphogenesis and levels of photosynthetic pigments in Gerbera jamesonii grown in vitro. Hortic Environ Biotechnol 59(1): 115-123. doi:10.1007/s13580-018-0012-4.

ROCHA PSG, DE OLIVEIRA RP, SCIVITTARO WB \& DOS SANTOS UL. 2010. Diodos emissores de luz e concentrações de BAP na multiplicação in vitro de morangueiro. Cienc Rural 40: 1922-1928. doi: 10.1590/S0103-84782010000900011.

RODRIGUES M, COSTA THF, FESTUCCI-BUSELLI RA, SILVA LC \& OTONI WC. 2011. Effects of flask sealing and growth regulators on in vitro propagation of neem (Azadirachta indica A. Juss.). In Vitro Cell Dev Biol Plant 48: 67-72. doi: 10.1007/s11627-011-9398-8.

SALDANHA CW, OTONI CG, DE AZEVEDO JLF, DIAS LLC, DO RÊGO MM \& OTONI WC. 2012. A low-cost alternative membrane system that promotes growth in nodal cultures of Brazilian ginseng [Pfaffia glomerata (Spreng.) Pedersen].
Plant Cell Tissue Organ Cult 110: 413-422. doi:10.1007/ s11240-012-0162-5.

SANATOMBI K \& SHARMA GJ. 2007. Micropropagation of Capsicum frutescens L. using axillary shoot explants. Sci Hortic 113: 96-99. doi: 10.1016/j.scienta.2007.01.020.

SANTANA-BUZZY N, CANTO-FLICK A, IGLESIAS-ANDREU LG, MONTALVOPENICHE MC, LÓPEZ-PUC G \& BARAHONA-PÉREZ F. 2006. Improvement of in vitro culturing of habanero pepper by inhibition of ethylene effects. HortScience 41: 405-409.

SANTOS RP, DA CRUZ ACF, IAREMA L, KUKI KN \& OTONI WC. 2008. Protocolo para extração de pigmentos foliares em portaenxertos de videira micropropagados. Rev Ceres 55: 356364. doi: /3052/305226703014/.

STEINITZ B, KÜSEK M, TABIB Y, PARAN I \& ZELCER A. 2003. Pepper (Capsicum annuum L.) regenerants obtained by direct somatic embryogenesis fail to develop a shoot. In Vitro Cell Dev Biol Plant 39: 296-303.

SWAMY BN, HEDAU NK, CHAUDHARI GV, KANT L \& PATTANAYAK A. 2017. CMS system and its stimulation in hybrid seed production of Capsicum annuum L. Scientia Horticulturae 222: 175-179. doi: https://doi.org/10.1016/j. scienta.2017.05.023.

VALNIR JÚNIOR M, VASCONCELOS AJF, LIMA LSS, SILVA KF \& CARVALHO CM. 2015. Eficiência do uso da água em pimenta da espécie Capsicum frutescens L., variedade tabasco. Appl Res \& Agrotec 8: 53-61. doi: 10.5935/PAeT.V8.N3.06.

VICTÓRIO CP \& LAGE CLS. 2009. Efeitos da qualidade de luz na germinação e desenvolvimento inicial in vitro de Phyllanthus tenellus. Rev Ciênc Agron 40: 400-405. doi: 1953/195317389011.

WELLBURN AR. 1994. The spectral determination of chlorophylls $a$ and $b$, as well as total carotenoids, using various solvents with spectrophotometers of different resolution. J Plant Physiol 144: 307-313. doi: 10.1016/ S0176-1617(11)81192-2.

XIAO Y, NIU G \& KOZAI T. 2011. Development and application of photoautotrophic micropropagation plant system. Plant Cell Tissue Organ Cult 105: 149-158. doi:10.1007/ s11240-010-9863-9.

YEH N \& CHUNG J-P. 2009. High-brightness LEDs-Energy efficient lighting sources and their potential in indoor plant cultivation. Renew Sust Energ Rev 13: 2175-2018. doi: https://doi.org/10.1016/j.rser.2009.01.027

\section{Abbreviations}

LED Light-emitting diodes

FL Fluorescent lamps

WL White LEDS 


\author{
RL Red LEDS \\ BL Blue LEDS \\ RBL Red/blue LEDs \\ CRD Completely randomized design
}

\section{How to cite}

GRIS T, PINHEIRO MVM, THIESEN LA, WEBLER AR, JUNGES DL, HOLZ E, NAIBO I, BATISTA DS, OTONI WC \& SCHMIDT D. 2021. Light quality and sealing type affect in vitro growth and development of Capsicum frutescens cultivars. An Acad Bras Cienc 93: e20190061. DOI 10.1590/00013765202120190061.

Manuscript received on January 19, 2019;

accepted for publication on September 28, 2019

\section{TAINARA GRIS ${ }^{1}$}

https://orcid.org/0000-0001-7229-9230

\section{MARCOS V.M. PINHEIRO 2}

https://orcid.org/0000-0002-5028-7818

\section{LEONARDO A. THIESEN ${ }^{3}$}

https://orcid.org/0000-0002-3439-842X

\section{ANDERSON R. WEBLER}

https://orcid.org/0000-0003-0744-4694

\section{DIÉSSICA L. JUNGES ${ }^{2}$}

https://orcid.org/0000-0002-4866-4178

\section{EVANDRO HOLZ 4}

https://orcid.org/0000-0002-8018-6743

\section{IURI NAIBO 4}

https://orcid.org/0000-0003-2281-0015

\section{DIEGO S. BATISTA ${ }^{5}$}

http://orcid.org/0000-0002-5798-7761

\section{WAGNER C. OTONI ${ }^{6}$}

https://orcid.org/0000-0002-9614-9373

\section{DENISE SCHMIDT ${ }^{4}$}

http://orcid.org/0000-0002-9963-4956

${ }^{1}$ Núcleo de Pesquisas em Biotecnologia e Desenvolvimento Vegetal, Universidade Federal de Santa Catarina/ UFSC, Centro de Ciências Agrárias, Rod. Admar Gonzaga, 1346, Itacorubi, 88034-000 Florianópolis, SC, Brazil
${ }^{2}$ Programa de Pós-Graduação em Agricultura e Ambiente, Universidade Estadual do Maranhão/ UEMA, Centro de Ciências Agrárias, Cidade Universitária Paulo VI, Tirirical, 65055-970 São Luís, MA, Brazil

${ }^{3}$ Programa de Pós-Graduação em Agronomia, Universidade Federal de Santa Maria/UFSM, Av. Roraima, 1000, Cidade Universitária, Camobi, 97105-900 Santa Maria, RS, Brazil

${ }^{4}$ Programa de Pós-Graduação em Agronomia Agricultura e Ambiente, Universidade Federal de Santa Maria/UFSM, Campus Frederico Westphalen, Linha Sete de Setembro, s/n, 98400-000 Frederico Westphalen, RS, Brazil ${ }^{5}$ Universidade Federal da Paraíba, Departamento de Agricultura, Campus Universitário III, Rua João Pessoa, s/n, 58220-000 Bananeiras, PB, Brazil ${ }^{6}$ Universidade Federal de Viçosa, Laboratório de Cultura de Tecidos LCTII/BIOAGRO, Departamento de Biologia Vegetal, Av. Peter Henry Rolfs, s/n, Campus Universitário, 36570900 Viçosa, MG, Brazil

Correspondence to: Marcos V. M. Pinheiro E-mail:macvini@gmail.com

\section{Author contributions}

Tainara Gris: Contribution to the conception and design of the study, data collection, data analysis and interpretation, scientific writing. Marcos Vinícius Marques Pinheiro: Contribution to the conception and design of the study, data collection, analysis and interpretation of data, scientific writing, and contribution to critical review. Leonardo Antonio Thiesen and Anderson Rafael Webler: Contribution to data collection, contribution to data analysis and interpretation. Diéssica Letícia Junges, Evandro Holz and Iuri Naibo: Contribution to data collection. Diego Silva Batista, Wagner Campos Otoni and Denise Schmidt: Contribution to the preparation of the manuscript, contribution to the critical review, adding intellectual content.

\section{(cc) BY}

